\title{
The implementation of population education in senior high school
}

\author{
$*^{1}$ Claver Nzobonimpa; ${ }^{2}$ Zamroni \\ *Department of English Language and Literature, Faculty of Languages and Social Sciences, \\ Université du Burundi (National University of Burundi) \\ UNESCO Avenue No. 2, P.O. Box 1550 Bujumbura, Burundi \\ *Email: nzobonimpacl@yahoo.fr
}

Submitted: 14 Juby 2017 | Revised: 27 December 2017 | Accepted:06 February 2018

\begin{abstract}
This research aimed to evaluate the implementation of Population Education in senior high school in terms of (1) learning process, (2) learning materials, (3) evaluation process, (4) course outcome, (5) teachers' role, (6) perception of Population Education, and (7) factors supporting and inhabitting Population Education. The research subjects were one teachers' supervisor, three teachers, and 65 students. The data were collected through questionnaires, interviews, and documentation and analyzed quantitatively using descriptive statistics. The qualitative data collected through interviews were used for deeper explanation. The research findings were: (1) the teaching process was not quite appropriate, (2) materials for Population Education were available and efficient, (3) the evaluation process was not appropriate, (4) the students were satisfied with the teachers' role, (5) the students' perception of Population Education was very positive, and (6) the constraints in Population Education included (a) limitation in time, (b) too many extracurricular activities, (c) rapid change of data, and (d) the validity of materials.
\end{abstract}

Keywords: population education, implementation, learning process, integration

\section{How to cite item:}

Nzobonimpa, C., \& Zamroni, Z. (2017). The implementation of population education in senior high school. REiD (Research and Evaluation in Education), 3(2), 124-132. doi:http://dx.doi.org/10.21831/reid.v3i2. 10024

\section{Introduction}

Education is very important for human being. Moore (2015, p. 1) says that: 'Changes in society are often in more demands being placed on our education system'. Further, as stated in Law No. 20 of 2003, Indonesian national educational system ensures equal opportunity, improvement of quality, relevance and efficiency in education to meet various challenges in the development of local, national, and global lives changes (UNESCO, 2015, p. 1). Syamsudin, Budiyono, and Sutrisno (2016, p. 26) inform that the goal of education in Indonesia is to develop learners' potentials so that they become Indonesian individuals with faith and fear of God, noble morals, good health, great knowledge, high competency, creativity, and independence, and become individuals who are democratic and responsible. In order to reach its education objectives, Indonesian government elaborates the curriculum which contains the objectives and strategy to achieve the education goals. In line with this opinion, Indonesian National Education Law of 2003 defines curriculum as "...a set of plan and regulations about the aims, content, materials of lessons and the methods employed as guidelines for implementation of learning activities to achieve given education objectives" (Dharma, 2008).

Population Education is one of the teaching programs delivered in schools. It is a 
program introduced due to the rapid population growth in both the industrial and developing countries. In early 1960s, the study of human reproduction, birth control, and also investigation of the cause and effect of population was included into the school curriculum (Sulistyo, 1997, p. 26). In secondary schools, the government integrated Population Education topic into six subjects: Biology, Geography, Economics, Civics, Physical Education, and Anthropology with the use of the integrative approach.

Though Population Education has been introduced in Indonesian formal education many decades ago, some problems still occur. There are still significant differences between the ideal situation (self-reported) and the actual practice related to teachers' roles in teaching Population Education. This difference indicates that there are role conflicts for teachers in teaching Population Education. Some observable barriers related to the implementation of Population Education are the lack of teachers' knowledge and skill, and also the lack of teachers' autonomy in carrying out teaching activities.

\section{Education}

John Dewey (Ornstein \& Levine, 1989, p. 10) considers education as a social process by which the groups of immature members, especially children, learn to participate in a group life. Thus, through education, children receive knowledge about their cultural heritage and learn to use it in problem solving. Hills (1986, p. 50) says that education has two principles: passing on knowledge from one generation to the next, and providing the people with skills which enable them to analyze, diagnose, and question something. Education, in the narrowed sense, is regarded to be equivalent to instruction. It consists of 'specific influences' given consciously to bring in the development and growth of the students. In general, education aims to transmit a common set of beliefs, values, norms, and understanding from the adult to the youth. Morality, on the other hand, aims to maintain the order in a society; to respect people as well as regard them holistically (Nayef, Yaacob, \& Ismail, 2013, p. 165).

\section{Population Education}

Viederman (V. K. Rao, 2001, p. 31) says that Population Education may be defined as an educational process which assists persons to (a) learn causes and consequences of population problems; (b) define the nature of the problems associated with population process and characteristics; and (c) assess the positive and effective means by which the society as a whole and he/she as an individual can respond to the areas that influence these processes in order to enhance the quality of life. Rao (2004, p. 34) says that: 'Population Education is an educational program which provides for a study of population situation in the family, community with the purpose of developing in the students' rational and responsible attitudes and behavior toward that situation'. Based on the definition, we can understand that Population Education is a program which provides a study of population situation at various levels. It also intends to develop rational and responsible attitudes and behavior to that situation.

\section{Learning}

Learning is identified as some kinds of change in behavior which is relatively long lasting. According to Schunk (2012, p. 3), the definition of learning is 'an enduring change in behavior, or in the capacity to behave in a given fashion, which result from practice or other form of experience'. Learning aims at changing the behavior of the learner. Learning is the main activity organized in school which has three main criteria: (1) learning involves change, (2) learning endures over times, and (3) learning occurs through experience.

Illeris (2009, p. 14) distinguishes the definition of learning into four. First, learning can refer to the results of individual learning processes. Second, learning refers to individual psychological processes that lead to alterations or results described as meaning. Third, learning, as well as processes of learning, refers to the interaction process among individuals, his/her material, and social environment described as meaning. Fourth, learning and process of learning are used identically with the word teaching. It may be interpreted as a result of tacit short circuit between what is taught and what is learned. 
In the discussion of learning activities, Assan (2014, p. 340) insists that learning activities, especially in adults, have three features, including the facts that: (1) the learners develop different outlooks and approaches with maturity and/or experience; (2) the learners reveal different degrees of independence in their learning; (3) the learners exhibit a different amount of involvement in, or different approaches to, learning tasks. The type of involvement is often dependent upon the context in which the learning activity takes place.

As far as learning theories are concerned, we distinguish the following learning theories:

Self-directed learning. Borich (2000, p. 273) has defined self-directed learning as an approach to teaching and learning that actively engages students in the learning process to acquire the high levels of behavioral complexity outcome. Mohammadi and Araghi (2013, p. 75) assert that self-directed learning refers to any self-teaching projects in which the learner establishes his specific goal, decides how to achieve it, finds the relevant resources, plans his strategies, and maintains his motivation to learn independently. Bear (2012, p. 28) argues that self-directed learning is a process which occurs when individuals take initiative, with or without the help of others, in diagnosing their learning needs, formulating learning goals, identifying human and material resources for learning, choosing and implementing appropriate learning strategies, and also evaluating learning outcomes.

Cooperative learning. Unlike self-directed learning, cooperative learning is defined as activities that involve groups of students jointly working through assigned tasks (after receiving instruction from the teacher) until all of the group members have successfully mastered and completed them (Johnson, et al., in Thanh, 2014, p. 3).

Discovery Learning. Joy (2014, p. 32) explains that learning happens by discovering, which prioritizes reflection, thinking, experimenting, and exploring. He also suggests that the discovery learning approach is closer to the concepts of exploration, discovering, invention and the 'knowledge cannot be transferred from one person to another' concept; instead, a student needs to experience an event in order to make it truly meaningful.

\section{Perception}

In the perspectives of social psychology, Walgito (2010, p. 99) defines perception as the process of organizing, and interpreting the stimulus received into something meaningful. In perception, the stimulus may come from the outside of the individuals (external) or within the individuals (internal). Furthermore, Mozkowit and Orgel (Walgito, 2010, p. 101) argue that perception is a global response to a stimulus. From those definitions, perception is viewed as the response to a stimulus or surroundings. Then these responses will be interpreted as meaningful information related to the stimuli.

\section{Teacher's Role in Population Education}

Malik, Murtaza, and Khan (2011, p. 784) determine the teachers' role in learningteaching processes as the persons who are responsible to ensure whether the teaching process puts emphasis on course context, interpersonal relationship, or on classroom discipline and control. The following cases are also taken into consideration by teachers: (1) the kind of learning being promoted by putting emphasis on the acquisition of skill, facts or understanding; (2) the pattern of communication in the classroom; and (3) students' communication, by keeping eye on the way in which educational tasks are organized.

Hudgins et al. (1983, p. 489) distinguish six roles of a teacher in the classroom. First, a teacher is a transmitter. In this role, his duty is to transmit factual information to students. Second, he is a socializer; he supervises the development of moral values and norms of his students. Third, he is an initiator and administrator of goals; he initiates and administers long-range and short-run activities and goals of the class membership. Fourth, he is an evaluator. He evaluates his students' academic performance. Fifth, he is a motivator; he motivates his students to realize their achievement potential. Sixth, he is a disciplinarian. His duty is to discipline and apply sanctions in response to the class members' behavior. 


\section{Method}

The main aim of this research is to find out the implementation of Population Education in senior high school. This research used a mixed method (quantitative data were analyzed under descriptive statistics method, then supported by qualitative data analysis). The basic assumption is that the use of both quantitative and qualitative methods in combination may provide a better understanding of the research problem and question (Creswell, 2010).

The research was conducted in a senior high school in Yogyakarta Special Region, Indonesia, from January to April 2016. The sample consisted of 65 students of class XI, three teachers (Sociology teacher, Economics teacher, and Geography teacher), and also one supervisor.

Documentation was used to collect the Population Education curriculum, students' books, and teachers books. The sample of the research is presented in Table 1.

Table 1. Research sample

\begin{tabular}{lc}
\hline \multicolumn{1}{c}{ Data source } & Rate \\
\hline Students & 65 \\
Teachers & 3 \\
Principals & 1 \\
Total & 69 \\
\hline
\end{tabular}

\section{Research Variables}

In this research, the aspects evaluated are: (1) the efficiency of the learning/teaching materials, (2) the appropriateness of the learning/teaching process and evaluation process, (3) the teachers' and students' satisfaction on Population Education outcome, (4) the efficiency of the evaluation process, (5) Population Education outcome, (6) the students and teachers' appreciation of Population Education, (7) teachers' role, and (8) the factors that facilitate or inhibit the learning process of Population Education.

\section{Data Collection Techniques}

This research used a variety of data collection techniques, i.e. questionnaires, observation, and interview. In order to collect the quantitative data, questionnaires were given to
65 students. The qualitative data were collected through classroom observations and an interview with four teachers of Sociology, Geography, Economy and one teacher who is in charge of monitoring the social studies program.

\section{Research Instruments}

The research involved the following instruments. The first one is observation guide and checklist. Observations were conducted in the beginning of the semester. Through these observations, the researchers collected information about school and its Population Education program. The researchers also checked the teacher's materials, students' text books and some teachers' facilities through checklist.

The second instrument is a questionnaire. The students were given an open and closed questionnaire. The questions were related to (1) the efficiency of the learning material, (2) the appropriateness of learning/teaching process, (3) teachers' and students' satisfaction on Population Education outcome, (4) efficiency of evaluation, (5) Population Education outcome, (6) students' and teachers' appreciation of Population Education, (7) teachers' role, and (8) the factors that facilitate or inhibit Population Education learning processes. The third instrument is an interview guide. The topics of the interview were identical with the questionnaire evaluation aspect.

\section{Validity and Reliability of Instruments}

Validity assessment was required to provide an evidence related to whether the instrument indeed accomplishes what it is supposed to accomplish (Teo, 2013). In this research, the face validity and content validity were used to validate the instruments by involving two experts in Social Studies. In order to check whether the research instruments measured what it was supposed to measure, a tryout test was administered. The tryout results had allowed the researchers to revise the content and form of some variables.

\section{Data Analysis Techniques}

The questionnaire applying modified Likert scale which is proposed by Mardapi 
(2008, p. 23) was administered to 65 students and analyzed using descriptive statistics. Table 2 shows the criteria for learning process, material, course, outcome and also perception of Population Education.

This analysis was followed by three key stages of analyzing qualitative data. Miles and Huberman in Irambona and Kumaidi (2015, p. 121) explain that the three stages of qualitative data analysis are data reduction, data display, and conclusion formulation. The qualitative data were reduced to make them simpler to analyze, then were summarized and formulated to a conclusion. This analysis was done during data collection, as well as after all of the data had been gathered.

\section{Findings and Discussion}

Findings

\section{Population Education Learning Process}

Based on the students' stand point, the learning process of Population Education is less appropriate. The mean score of the students' rating is 29.6, which means that most students chose 'sometimes' category. Based on the interview with Geography, Economics and Sociology teachers and the teachers' supervisor, it is discovered that Population Education is not planned as an integrated lesson. The researchers also discover that there are some opinions related to Population Education, including: (1) Population Education is not popular, (2) some teachers do not have any concern in teaching Population Education in their courses, (3) Population Education is not a prominent material in social science class, (4) Population Education course taught only concerns Indonesia and East Asia issues.

\section{Learning Materials}

Questions were asked to the students in order to discover the efficiency of learning material and sources which are used in Population Education learning process. It is revealed that students are satisfied with the materials. This is reflected by the number of students who chose 'always' and 'often'. There are $43.07 \%$ of the students who chose 'always' category. Meanwhile, 24 students or $36.92 \%$ of all students chose 'often' category. The rest of the sample is in the two remaining categories. There are 12 students choosing 'sometimes' and only one student chose 'never' category. The mean score of learning material efficiency is 14.17 and it is included in 'often category'.

According to the interview with the teachers, the researchers discovered that the material/books related to Population Education are easily found. It is also discovered that mass media help teachers to improve and update their learning material. Television, newspapers, internet and other information technology help the teachers and students as the learning sources of references.

\section{Evaluation}

The objective of this research is to find out whether the students are given assignments and instruction to discuss population issues inside/outside of the class. The researchers found that the students' opinion on the evaluation appropriateness is less appropriate. There are only seven students $(10.77 \%)$ who chose 'always' category. Meanwhile, 16 out of 65 students $(24.61 \%)$ chose 'often' category, while more than half of the students chose 'sometimes' and 'never'.

Table 2. The criteria of learning process, material, course, outcome and perception

\begin{tabular}{lll}
\hline \multicolumn{1}{c}{ Score $\mathbf{X}$} & \multicolumn{1}{c}{ Categories } & Predicate \\
\hline $\mathrm{X} \geq \mathrm{M}+1 \mathrm{SD}$ & Strongly agree/ Always & (Very)Satisfying/Positive/Good/Appropriate \\
\hline $\mathrm{M} \leq \mathrm{X}<+1.5 \mathrm{SD}$ & Agree/Often & Satisfying/Positive/Good/Appropriate \\
\hline \multirow{2}{*}{$\mathrm{M}-1 . \mathrm{SD} \leq \mathrm{X}<\mathrm{M}$} & Disagree/Sometimes & (Less) satisfying/appropriate \\
\cline { 2 - 3 } & & Negative/Bad \\
\hline $\mathrm{X}<\mathrm{M}-1 . \mathrm{SD}$ & Strongly disagree/Never & Not satisfying/ Not appropriate/Very Negative/Very bad \\
\hline
\end{tabular}


Based on the interview, the teachers gave assignments related to Population Education issues, but only if the subjects being taught (Geography, Sociology, and Economics) contained population issues. It is also discovered that Population Education has a limited time allocation. As a consequence, the items introduced in assignments are quite few. The teachers plan a discussions in class by giving a specific topics. Mostly, the topics are given to be discussed in class. They are not encouraged to do discussion on Population Education outside the classroom.

\section{Teachers' Role in Population Education}

The role of teachers in Population Education is appropriate. In fact, the indices of appropriateness are close to the 'appropriate' category, i.e. 0.87 . The students are satisfied with the role of teachers as managers, guiders, instructors, judges, and parents of Population Education learning process.

\section{Perception on Population Education}

It is discovered that the perception of Population Education's mean score is 27.38 which is in 'strongly agree' category. There are 31 out of 65 students $(47.70 \%)$ who chose 'strongly agree'. The remaining students are in the category of 'agree'. It can be concluded that students are satisfied with the implementation of Population Education learning process. Based on the interview, it is discovered that students are interested in Population Education and the teachers expressed that population is interesting since it deals with actual issues which are faced by the nation which students meet in their daily life.

\section{Factors Facilitating Population Education}

There are several factors that facilitate Population Education in senior high school, including (1) students' motivation to learn Population Education, (2) materials availability in school library, (3) time allocation, and also (4) extracurricular activities. The factors which inhibit Population Education are limited time allocation, unfamiliarity of the teachers with the topics, and also invalid/out-ofdate materials which are avaliable in the learning process.

\section{Discussion}

\section{Learning Process in Population Education}

In general, some Population Education topics are integrated in some courses (Geography, Economics, and Sociology). Though those three courses are integrated with Population Education, only Geography teachers prepare an entire lesson about Population Education because Population Education is not the main focus of the courses. Population Education is a small part of those courses with limited time allocation.

\section{Materials in Population Education Learning}

Based on the findings, materials in Population Education are available. Concerning students' opinion on Population Education materials related to its availability and usage, the mean score is in 'often' category with the score of 14.17. The sources for Population Education learning material are not only available in school library, but also are collected from the Internet and mass media

\section{Evaluation in Population Education}

Population Education is integrated in Geography, Economics, and also Sociology courses. From the findings, students' opinion related to the evaluation process is in the category of 'sometimes'. The examinations and assignments which are given in these courses contain few items about Population Education. The evaluation of Population Education shows that teachers included few Population Education items in their exams and assignment. It is also discovered that the time allocation for Population Education in class is insufficient.

\section{Teachers' Role in Population Education}

In this section, it has been found that students and teachers are satisfied with the role of teachers in Population Education and other courses. In fact, teachers have the roles of being managers, guides, instructors, judges, and parents. In this research, it has been realized that teachers give instructions to students at the beginning of each lesson. Teachers take strategies to help and guide students. In order to install motivation to students, they bring 
hot news as the topics. This allows students to be motivated and participated more in the class. As parents, teachers care about the students' future life by bringing the topics that are concerned with their future to discuss, such as unemployment and awareness on competition in the work field.

However, it has been realized that students are not asked and reminded to make discussion about population issues out of the class. Discussions outside the class reinforce knowledge and help students to learn about Population Education in a natural way. This would extend their awareness of population issues that they may face in their life.

\section{Perception of Population Education}

The research found that students are interested in Population Education and find that it is very useful to learn it. Perception of Population Education is one of the variables that is very favorable (most students chose 'strongly agree'), which means that students' perception of Population Education is very positive. Population Education is connected to every aspect and issue of life. To be very clear, Population Education is very factual, so that it can be easy to understand. Teachers find that Population Education is very important to students. Through Population Education, the teachers have a chance to talk about the real life, and also to draw a picture of Indonesia in terms of population.

\section{Factors Supporting and Inbibiting the Teaching of Population Education}

There are some factors that support the teaching of Population Education. The first factor is that Population Education deals with everyday-life issues. Students get motivated to learn it since it talks about everyday life in simple and factual way. Second, the dynamism of Population Education topics can be found everywhere. It is not difficult to get information about Population Education topics as well as population issues. The third factor is the availability of materials to be used.

On the other hand, there are some factors which constrain to Population Education. The first factor is time allocation. The time allocation for Population Education is limited, so that the topics of Population Education are not suffieciently exploited. Second, the students are obliged to join various extracuricullar activities that spend their time, so that the time to revise of their learning material is limited. The extracurricular activities are paid by students themselves; there is no support from school. The students are asked to do what they can do to get the money to pay the cost for those activities. They are stressful with these extracurricular activities and it can diminish their motivation to learn. Third, the teachers are not familiar with Population Education. It has also been found that the teachers are unable to catch the dynamism of Population Education materials. Fourth, although some books of Population Education are available in the newest edition, the content of the books are relatively out-of-date, while the information which is gained from the mass media and the Internet are sometimes not valid.

\section{Conclusion and Recommendations}

\section{Conclusion}

Based on the findings and discussion, it can be concluded that: (1) the teaching process of Population Education in senior high school is less appropriate; (2) the Population Education materials are avaliable in the library, mass media, and the Internet; (3) the evaluation in Population Education learning is less appropriate. The items are included in the assignments and examinations, because the teachers allocated limited quota for Population Education items; (4) the teachers' role in Population Education is appropriate, especially in bringing the actual topics to motivate the students; (5) the students' and teachers' perception of Population Education is very positive (they consider Population Education an important thing to learn); (6) the favorable factors of Population Education are the recency of the topics, dynamism of the topics, and avaliability of the materials. The factors which inhibit Population Education are the limited time allocation, teachers' unfamiliarity with the topics, and invalid/out-of-date materials. 
Recommendations

Referring to the research results, some recommendations are proposed, including: (1) Additional time allocation is needed for Population Education; (2) students and teachers should get more time to be involved in population issues through seminars; (3) the government should support the Population Education teachers with up-to-date data in order to ensure the validity; (4) the authorities need to reduce the time allocation for extracurricular activities; (5) teachers should be more consistent in their teaching activities by inviting students to be more concerned with population issues.

\section{References}

Assan, T. B. (2014). Perceptions of lecturers on quality assurance in higher education teaching and learning process. International Journal of Educational Sciences, 7(2), 339-347. https://doi.org/10.10 80/09751122.2014.11890196

Bear, A. A. G. (2012). Technology, learning, and individual differences. Journal of Adult Education, 41(2), 27-42.

Borich, G. D. (2000). Effective teaching methods. London: Prentice Hall.

Creswell, J. W. (2010). Research design qualitative, quantitative, and mixed methods approaches (A. Fawaid, trans.). Yogyakarta: Pustaka Pelajar.

Dharma, A. (2008). Indonesian basic education curriculum: Current content and reform. Presented in Roundtable Discussion in Retrac Governing Board Meeting at Institut Aminuddin Baki, Genting Highland, Malay-sia, on 27 August 2008. Jakarta: Ministry of National Education. Retrieved from http://www.ibe.unesco. org/curricula/indonesia/io_befw_2008 _eng.pdf.

Hills, P. J. (1986). A dictionary of education. New York, NY: Routledge \& Kegan Paul.

Hudgins, B. B., Phye, G. D., Schau, C. G., Theisen, G. L., Ames, C., \& Ames, R. (1983). Educational psychology. Itasca, IL: Peacock Publishers.
Illeris, K. (2009). The three dimensions of learning: Contemporary learning theory in the tension field between the cognitive, the emotional and the social. Malabar, FL: Roskilde.

Irambona, A., \& Kumaidi, K. (2015). The effectiveness of English teaching program in senior high school: A case study. REiD (Research and Evaluation in Education), 1(2), 114-128. https://doi. org/10.21831/reid.v1i2.6666.

Joy, A. (2014). Impact of discovery-based learning method on senior secondary school physics. IOSR Journal of Research \& Method in Education, 4(3), 32-36. Retrieved from www.iosrjournals.org.

Law No. 20 of 2003 of Republic of Indonesia on National Education System (2003).

Malik, M. A., Murtaza, A., \& Khan, A. M. (2011). Role of teachers in managing teaching learning situation. Interdisciplinary Journal of Contemporary Research in Business, 3(5), 783-833. Retrieved from http://journal-archieves8.webs.com/7 83-833.pdf.

Mardapi, D. (2008). Teknik penyusunan instrumen tes dan nontes. Yogyakarta: Mitra Cendekia.

Mohammadi, P., \& Araghi, S. M. (2013). The relationship between learners' selfdirected learning readiness and their English for specific purposes course accomplishment at distance education in Iran. Studies in Self-Access Learning Journal, 4(2), 73-84. Retrieved from http:// sisaljournal.org.

Moore, K. D. (2015). Effective instructional strategies: From theory to practice (4th ed.). Los Angeles, CA: SAGE Publications.

Nayef, E. G., Yaacob, N. R. N., \& Ismail, H. N. (2013). Taxonomies of educational objective domain. International Journal of Academic Research in Business and Social Sciences, 3(9), 165-175. https://doi.org/ 10.6007/IJARBSS/v3-i9/199.

Ornstein, A. C., \& Levine, D. U. (1989). Foundations of education. Dallas, TX: Houghton Mifflin. 
Rao, D. B. (2004). Teachers' population education awareness. New Delhi: Discovery Publishing House.

Rao, V. K. (2001). Population education. New Delhi: A.P.H. Publishing Corporation.

Schunk, D. H. (2012). Learning theories: An educational perspective. Upper Saddle River, NJ: Pearson/Merrill Prentice Hall.

Sulistyo, D. (1997). Role perception and professional commitment of high school population education teachers: A case study in Yogyakarta Province, Indonesia. Doctoral dissertation, Florida State University, Tallahassee, FL.

Syamsudin, A., Budiyono, B., \& Sutrisno, S. (2016). Model of affective assessment of primary school students. REiD (Research and Evaluation in Education), 2(1), 25-41. https://doi.org/10.21831/ reid.v2i1.8307
Teo, T. (2013). Handbook of quantitative methods for educational research. Dordrecht: Sense Publishers.

Thanh, P. T. H. (2014). Implementing cross-culture pedagogies: Cooperative learning at Confucian heritage cultures. Dordrecht: Springer Science Business Media.

UNESCO. (2015). Transforming teaching and learning in Asia and the Pacific: Case studies from seven countries. (E. Hau-Fai \& U. Miura, Eds.). Bangkok: The United Nations Educational, Scientific and Cultural Organization and UNESCO Bangkok Office. Retrieved from http://unesdoc.unesco.org/images/002 3/002329/232909E.pdf

Walgito, B. (2010). Pengantar psikologi umum. Yogyakarta: Andi. 